\title{
Infinite Interpretations? A Corpus-based Study for the Identification and Interpretation of Competing Frames in Parliament- representations in Hungary
}

\author{
Ágnes Virág \\ 0000-0002-3746-9916 \\ Eszterházy Károly University of Eger, Hungary
}

\begin{abstract}
Political communication highly depends on generic figurative frames such as Politics Is War, Object, Sport, Art and Politics Is Landscape. Regarding political art, it is suggested that artists use complex cognitive solutions (e.g. parallel issue-specific frames) in creative ways which are connected with one of the major generic frames. The study discusses parliament-representations (made between 2006 and 2015) which are not only attractive elements of the cityscape; thus, not literary representations of the building. Using the method of visual framing, the analyses (1) describe the artworks, (2) interpret the occurring symbols and metaphors determined contextually, and (3) reveal the ideological and power relations. Summing up, political artworks can be comprehended according to conventional mental schemas. However, artists usually create a minimum of two competing specifications of the general frames occurring at the same time, and let the viewer choose the one that fits better with their worldview.
\end{abstract}

KEYWORDS: competing frames, visual metaphor, metonymy, political art, Hungarian Parliament.

\section{INTRODUCTION}

During the period between 2006 and 2015, several artists ${ }^{1}$ chose the symbol of the Hungarian Parliament in order to express their thoughts and feelings about public life, the public atmosphere, or the past era in Hungary. Artists interviewed for this article argued that they were not doing politics, nor communicating direct

1 For example, Krisztina Nagy (Tereskova), Kriszta Nagy is chairing in front of the Parliament because she is chairing better than her compatriots in the parliament, 2006; Csaba Nemes, Remake, 2006; János Kósa, Media, 2008; József Szolnoki, Hun volt, hun nem volt, 2008; Dezső Szabó, Piss Parliament, 2009; Marko Rodics, Parliament, 2010; Borsos Lörinc, Immovable Land, 2010; 
policy to people, even if they depicted the Parliament building. According to the Interpretative Dictionary of the Hungarian Language (2016), 'parliament' means national assembly, supreme state power and legislative body. 'Országház' (literally 'Country House', or parliament) is the building itself, where the representative body meets. Consequently, the following questions arise: how can an artist use such a concrete political symbol in a way that differs from its concrete meaning as a building, or part of a cityscape, and how might this visual symbol be used in a way different from a simple political statement?

The purpose of this article is to empirically demonstrate that the interpretations of contemporary artworks depicting the parliament are limited by the use of figurative framing (coined by C. Burgers et al. 2016), but not restricted to a single meaning. Nevertheless, figurative framing is refined in quite complex and creative ways by the artists. We will only discuss the phenomena of distinct competing frames and contradictory specifications of frames due to space limitations. The present article addresses two main questions: 1) to what extent is it possible to identify any of the generic frames conventionally used in political discourses in the sense of artworks showing the parliament and 2) what sorts of emerging ideologies can be detected in relation to parliament-representations and how are they realized within the frames offered. These questions are explored by examining the following artworks: Marko Rodics Parliament (literally 'Country House’) (2010), Dezső Szabó Piss Parliament (2009), Borsos Lőrinc Immovable Land (literally 'Immovable Country') (2010), Bianka Dobó Clean court, tidy house (2014), Kriszta Nagy Tereskova Kriszta Nagy is chairing in front of the Parliament because she is chairing better than her compatriots in the parliament (2006), András Cséfalvay Comspognation: Nation state through the eyes of a dinosaur (2012-14), and Ágnes Eperjesi Words of Power (April 13, 2015). All of these are provided as examples of political art.

Research on art from a visual framing theory perspective or within metaphor studies (especially the multimodal ones), is sporadic in the field of cognitive semiotics, cognitive linguistics and communication studies. While earlier studies have focused on the genre of political cartoons (Gombrich, 1963), surreal art (Forceville, 1988; Carroll, 1994) as well as Rembrandt's self-portraits (Rothenberg, 2008); there has been a more recent turn towards political art pieces such as graffities (Poppi \& Kravanja, 2019; Stampoulidis \& Bolognesi, 2019), with a particular focus on their sociopolitical determinants. In a similar vein to these more recent graffiti-based studies, this study assumes that the interpretation is a creative and dynamic communicative procedure dissimilar from

András Cséfalvay, Compsognation, nation state through the eye of a dinosaur, 2012-14; Bianka Dobó, Clean court, tidy house, 2014; Ágnes Eperjesi, Words of Power, April 13, 2015; Nóra Soós, There is No Time, 2015. 
Conceptual Metaphor Theory (Lakoff \& Johnson, 1980). The corpus investigated here belongs to the genre of political art, which is considered to be a type of critical art as it deals with public affairs, reflects on public life critically, questions the truth of community-related processes and raises its possible alternatives, or possible interpretations.

The overview of the paper is as follows. The next section presents the justification of the selected theme. The third section provides insights into the literature of framing (Brugman, Burger \& Steen, 2017; De Vreese, 2005; Entman, 1993; Goffman, 1974) and summarizes the results so far within the experimental methodology of visual framing (Rodriguez \& Dimitrova, 2011). The theoretical section ends with a presentation of the notion of competing frames (Lakoff, 1996). The fourth part displays possible analyses of artworks with the aim of showing the operation of competing frames during the process of comprehension. It also intends to pinpoint the influence of the competing frames on an imagined viewer's interpretation. Therefore, it provides multiple interpretations of the chosen artworks. In the conclusion the results are discussed.

\section{CULTURAL POLICIES IN HUNGARY}

The period between 2006 and 2015 saw radical changes in the Hungarian cultural policy. Luca Kristóf (2017) argues that the government tends to rewrite the cultural canon through the Fundamental Law. By analyzing the repositioning of the Hungarian Academy of Arts (MMA) and the director turnovers of the National Theatre and the New Theatre, she concludes that even if patriotism, nationalism and Christian allusions are repeated features of the governmental cultural policy, and those are usually interconnected topics, it does not mean a coherent ideology. Instead it is more about the redistribution of positions and resources for new cultural and loyal elite. Similarly to József Mélyi (Artportal, 2014), Kristóf mentions that this cultural political model means that the government influences the production, the distribution and also the reception of cultural products, services and experiences (2017, p. 130).

The international organization dedicated to artistic freedom, Freemuse ${ }^{2}$, reported (2019) that Hungary was among the list of countries where violence was committed against artistic projects or institutions in 2018. The author of Freemuse's report classifies the methods of soft repression adopted by the Hungarian government into several groups: 1) personnel changes in cultural

2 Freemuse is an independent organization that monitors the state of artistic freedom worldwide, and it summarizes the tendencies of harassments against artists and their projects yearly. It also gives statistical information regarding the places, the various genres, and about the types and numbers of violations. 
institutions; 2) "buying out the media"; and 3) "using regulatory changes and politicizing committees of public funds to pressure potentially critical voices into self-censorship" (Freemuse, 2019, p. 84). The previous Freemuse report (2018) already issued a warning about the ongoing cultural changes:

2017 was the year of a new rise of popular nationalist politics in the US and Eastern Europe, built on Brexit, the Trump election and nationalist rhetoric in Poland and Hungary in the previous year. [...] The rhetoric of hate and attacking messages from populist-nationalist leaders over a period of time creates legitimacy in dismissing "others" who are different, resulting in wide intolerance. This has created an enabling environment for large-scale and systematic violations of freedom of artistic expression as we have witnessed in 2017 (Freemuse, 2018, p. 28).

Cultural changes in this period are particularly significant for understanding the discourses for which the examined artworks are used. There is the privileged position of MMA such as getting extra financial support, real estates, and membership in the committee evaluating artistic tenders. The cultural community could also be familiar with the protest movements, such as Ludwig Stairs (nemma, 2013) made in support of Barnabás Bencsik, the ex-director of the museum, as well as the demonstrations of Free Artists' Group (Magyar Narancs, 2012) aimed at preserving the freedom of Kunsthalle in Budapest. The Freemuse report also notes that censorship, as a reinvented form of attack, has been present in the field of visual art, literature and theatre since 2017 (e.g., against the visual artists Borsos Lőrinc, János Brückner).

Actors of cultural communities are worried. They did not find the ideology of the program Quality in Culture of 2009 (Cultural Strategical Basics of Hungary) was sufficiently reassuring, which was not alleviated by the Prime Minister's statement about the new cultural epoch (in July 2017): "A new intellectual and cultural approach is needed. We are facing major challenges from September" (Népszava, 2018). Artistic reactions differ on a wide range (Artportal, 2015) and the actors of the cultural sphere are facing decisions such as do I accept a certain award or fee? Do I take responsibility for organizing a particular exhibition? Do I apply for a certain tender? Do I take system criticism, or is the department's position more important?

These questions as well as some of the aforementioned cultural political changes were reoccurring topics within the interviews that were conducted with artists for this article, aimed at better understanding the contextual factors (cultural, historical and so forth) and the artists' motivations concerning the artworks in which the Hungarian Parliament appears visually. The earliest critical use of this symbol which I was able to detect occurred in the late 1980s. 
Hungarians participated in the section of Documenta 8 in Kassel of 1987. At that time, in a collaborative multimedia environment and action, János Sugár, Áron Gábor and Gábor Roskó used their bodies as a Budapest panorama: bridge, bridgehead and ship were used to refer the problem of physical and intellectual relationship and distance, while the paper model of the Parliament was cut in half during the last performance (Balázs, 2018, p. 43). In terms of its critical stance, it was no different when in 1988, Tamás Király presented his geometric-constructivist clothes including his system critical outfit in which the model wore the dome of the Parliament with a red star as a hat (Figure 1). This was also on display at the avant-garde show called Dressater in West Berlin, which led to an international career for Király. All the artists mentioned here, intended to express their emotions and thinking in relation to Eastern Europe and the international art scene, more specifically the West.

Figure 1. Tamás Király (1988). Geometric-constructivist clothes and the Parliament-set

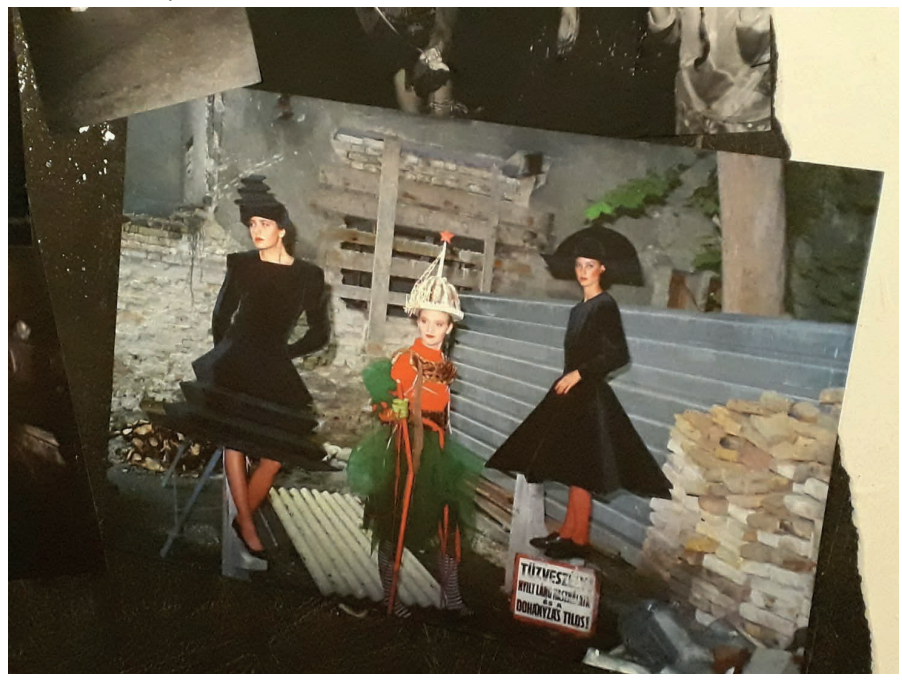

Source: The photo was taken at the exhibition Black Hole in the Museum of Kiscell, Óbuda

\section{FRAMING THEORIES}

Framing as a concept is used in several scientific fields including sociology, political science and communication theory (Brugman \& Burgers, 2018). Within framing, certain aspects of the experienced reality are chosen and highlighted during communication in order to define a problem, shed light on its causation, allow for a moral evaluation, and provide a solution (Entman, 1993, p. 53). A frame should be differentiated from another frame, and should be recognizable 
by anybody; thus, it is not based on the researcher's fantasy (Capella \& Jamieson, 1997, p. 47, 89).

Frames can be investigated in terms of frame-building (Burgers, Konijn \& Steen, 2016) which helps to conceptualize the mental schema from the viewpoint of its creator. Nevertheless, society itself, social influence on the person and on the society also play an important role in the process of frame-building (De Vreese, 2005). As such, analyses of artworks provide insights into the frame-building process.

Framing can take place through both linguistic and visual metaphors (Krippendorf 2017, p. 97). Metaphoric framing is highly dependent on the cultural context and the political topic (Brugman, Burgers \& Steen, 2017, p. 11), which is also accompanied by moral evaluation. Moreover, themes can be placed into various conceptual frames which can support or conflict with each other. When a viewer encounters alternative frames, he then chooses that particular frame which best fits his worldview, and his decision is independent of his interests in political subjects. In addition, the viewer shapes his worldview along competing, sometimes incompatible frames that refer to the same topic (Sniderman \& Theriault, 2004). The acceptance of a certain frame is mostly unconscious; and probably in line with the viewer's previous moral and political attitude (most probably the alternative frame does not emerge at all for the viewer, because he is satisfied with the interpretation which is the easiest to reach for him). The metaphor might be grasped when the source domain is salient enough and is able to change the perspective of the viewer regarding the topic itself.

We must also keep in mind that images are able to hide certain things, or to push facts into the background (Wischmann, 1987, p. 70) and visual framing is one of the tools to highlight certain aspects. For example, Rodics's Parliament recalls the concept of a Plush Toy, and pinpoints childhood, emotion-based communication, flippancy (the 'it is just a game, and not more' attitude) and momentary entertainment, but also a non-toy quality (through its grey color), and critical, objective distancing. It wants to compete with huge plush bears through its extra size (1.5 $\mathrm{m}$ long), but it fails because of its form recalling the building of the parliament, and because of its impersonal character. By choosing this type of toy, the frame can be described as a role play as the structure has no strategical element; there is no chance of winning (like in chess or boxing, which are common sources in political metaphors). Instead, the plush provides a game based on roles and emotions.

There are at least three methods of determining visual frames. The first type works with thematic concepts (Patridge, 2005) and the second one identifies frames according to the ideological background (Griffin \& Lee, 2005). The third type was developed by Rodriguez and Dimitrova (2011), who use their process on four levels. On the first level they understand the visual entity (generally a photo) as a denotative system. They describe the image and group entities 
close to each other, comparisons are made, while the visual elements - placed in the same environment but a bit farther - are considered as the visual context of the main entities. Rodriguez and Dimitrova investigate social distance, visual modality (color, depth, tonal features) and the actors' behavior on the second level. (This level was not considered during the present analysis.) Visual analysts comprehend the visual entities as connotative systems on the third level. A culture dependent interpretation of symbols and metaphors often appear on this level. Visual artworks are considered as ideological representations on the fourth level which considers questions such as: whose interests does the artwork serve; what kinds of ideas are dominant in the piece of art; or whose voice can be heard? The experts aim to reveal power relations similar to critical content analysis (Rodriguez \& Dimitrova, 2011, p. 57). In this paper, after the description of the image, the research focuses on the third and the fourth level.

\section{ANALYSIS AND FINDINGS}

Britta C. Brugman et al. (2017) identified five generic metaphoric frames in political communication on the basis of a systemic corpus research (involving 319 studies): politics is war (part of frames strategy and conflict), politics is an object (part of frame value), politics is sport and game (part of frame game), politics is art and images (part of frame image), and politics is a landscape (part of frame view). We will see that artists used similar frames, including war, object, game, and landscape during their work processes. following the tradition of critical art, they have created artworks that require interactive discourses and dynamic processes; thus, the viewers' decisions about the most appropriate frames for them are based on the competing mental schemas created by the artist.

\section{EXAMPLE 1: MARKO RODICS, PARLIAMENT 2010 (PLUSH, LENGTH 1.5 M)}

As we shall see further on, most of the examined artworks focus on political structure. The first example has already been discussed in terms of the frames' ability to highlight certain properties of the target. Consider Figure 2 that shows the aforementioned huge plush toy, Parliament (literally Országház, or 'Country House' in Hungarian) which was originally created by the artist group K27 (although the work was linked exclusively to one of its members, Marko Rodics after the group disbanded). Parliament is one piece from a collection of twenty-seven objects, which were exhibited in a show MủLabor in a mechatronic high school. The objects are examples of typical genres of artworks such as readymade, collage, painting, sound installation, performance art, object, photo, and so on. They aimed to present a range of genres to students, who do not 
often encounter contemporary art. The plush parliament belonged to the group of objects that represented the category of political art.

Figure 2. Marko Rodics (2010). Parliament, plush, length $1.5 \mathrm{~m}$

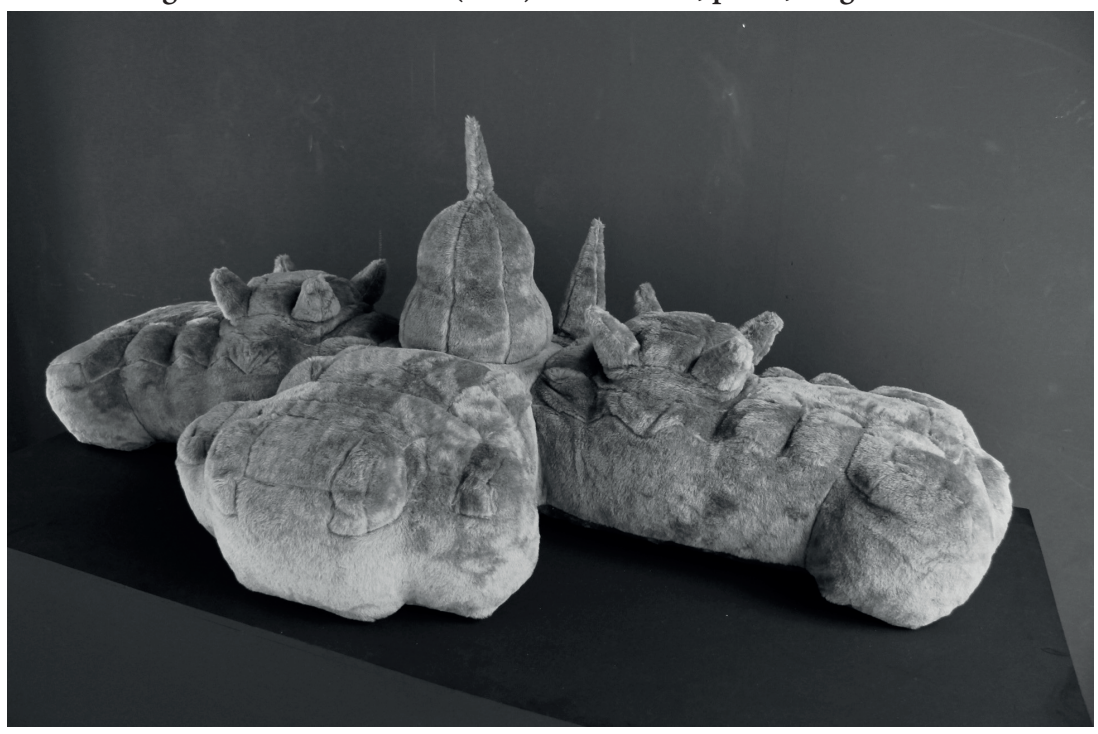

The basic idea can be linked to Marko Rodics, who was a member of a radical group called Foundation for National Art. According to the artist, nationalist voices strengthened in the early 2010s. For example, the appearance of the party Jobbik (Party for a Better Hungary with radical nationalist views) and the Nemzeti Gárda (National Guard) were novel phenomena in the political scene, while the MMA (Hungarian Academy of Arts) also began to grow, getting more and more financial support from the Hungarian state. At that time, these happenings touched people emotionally. "Honesty and respect disappeared from the building of the parliament" Rodics says, adding: "I do not care who is attracted to the left, or to the right side, I am not committed to either side. I do system critical art" (personal communication, August 31, 2018).

Parliament is a 1.5 meters long, grey plush building, a neo-pop object that was planned by Péter Gurszki, with the help of a 3D program, and was sewn by hand by Réka Mózes. The building is transformed metaphorically into a huge plush toy. Hence, its meaning depends on the viewer's interpretation and on who they consider to be the toy's owner. According to Rodics, a viewer may think that Parliament Is A Playhouse in which the politicians play childish games instead of representing the population's interests. An alternative reading is that Parliament Is A Plush Toy and the politicians are conceptualized as children. The plush toy as a type of game references emotional, touch-based communication. 
If Parliament Is A Plush Toy and is owned by the citizens, then Citizens Are Children. This interpretation reflects on the manifestation of the metaphor Nation Is A Family, in which the government is seen as parents and the citizens are conceptualized as children. According to Lakoff (1996), conservatives prefer the Strict Father model, while liberals apply the Nurturing Parent model during their decisions and activities. A viewer who applies the metaphor Parliament Is A Plush Toy most probably agrees with the Strict Father model, and imagines the politicians as parents, and himself as a child. The Plush Toy is comparable to the attractive image of a large plush bear that provides security.

The art group K27's object discusses the political system in a general frame of game that is mentioned among the five most often used metaphorical interpretations of politics by Brugman, Burgers and Steen (2017). In most cases, politics is understood as a strategic game in which there are decisions and logical steps (such as in chess); and where the players may win or lose the game. Rodics and his companions rewrite conventionally used game modes by choosing an untypical toy that is not a usual element of the political discourse. The artists manage to activate competing frames through the challenging choice of a game, and create a novel metaphor of Game (Politics Is Playing With A Plush Toy) by using an unusual type of toy in political discourse (ordinary toys would be chess or other logical games).

\section{EXAMPLE 2: DEZSŐ SZABÓ, PISS PARLIAMENT 2009 (OBJECT, INSTALLATION, PHOTO)}

Dezső Szabó created Piss Parliament (Figure 3) for the exhibition titled Kis magyar pornográfia ('Small Hungarian Pornography', a novel written by Péter Esterházy in 1991) in MODEM (Centre for Modern and Contemporary Art) in Debrecen in 2009. In that year, the twentieth anniversary of system change was celebrated. Szabó paraphrased Andres Serrano's artwork Piss Christ (1987), by drawing on the previous work both visually and verbally. Piss Parliament was also on display in the exhibition What is Hungarian in Kunsthalle of Budapest in 2012, where György Fekete (president of the MMA at that time) judged the art piece without mentioning the artist's name. He said that the work shows the "parliament [that] is soaked in pee." According to Dezső Szabó, if his name had been mentioned, then he could have had the opportunity to express his interpretation of the work to the audience, and he could have told them that "the work is not about desecration of Kunsthalle; instead, it's more about the entire Hungarian democracy that the political elite managed to pile up" (personal communication, April 13, 2018). He adds: 
I usually do not make direct political works. My private opinion is another matter. Political events happening after the system has changed summarize the missed opportunities caused by the Hungarian political elite with all its actors. I made this work to express my thoughts about the last twenty years. (ibid.).

Szabó bought a ten-liter aquarium in a pet shop, before looking for an appropriate parliament-shaped souvenir. While he purchased several, they were not the right ones, in terms of size or color. Finally, he chose one of them but removed the paint from it and carved it a little bit in order to obtain better proportions. The right amount of urine was collected over the course of a couple of days and became darker and darker as time passed and the protein precipitated. The artist took some photos of the object with a $35 \mathrm{~mm}$ SLR.

Figure 3. Dezső Szabó (2009). Piss Parliament, object, installation, photo

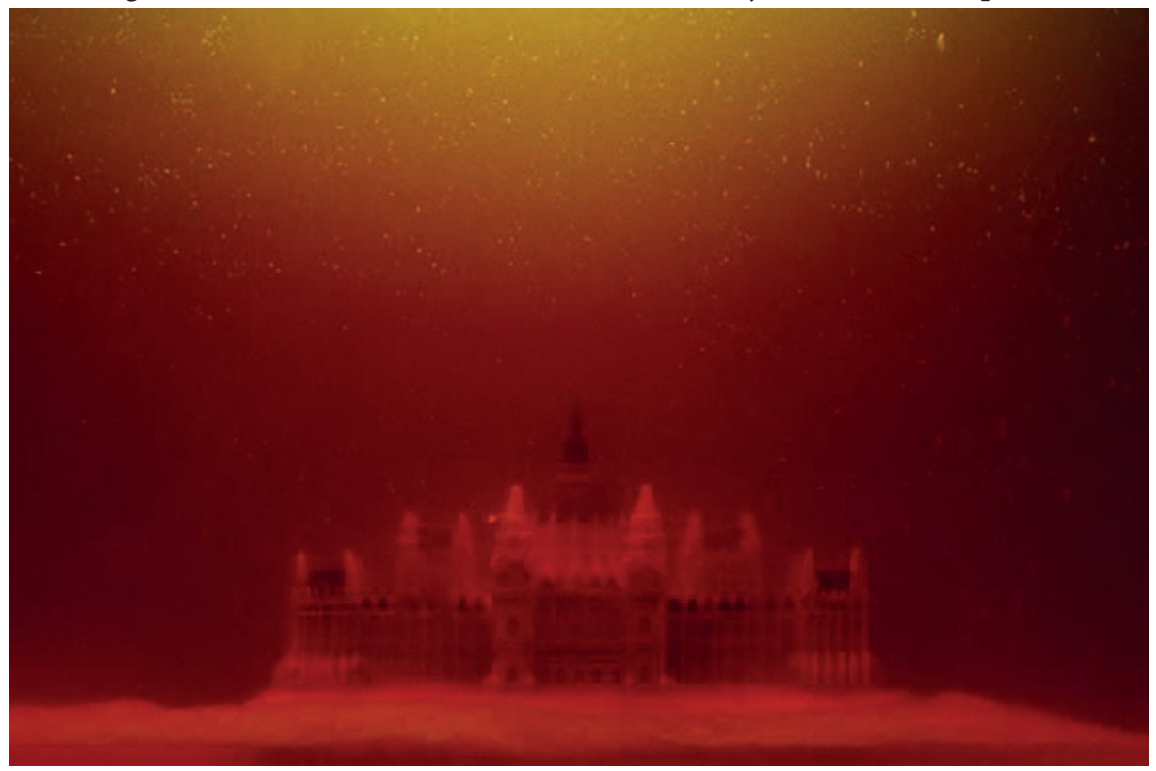

Szabó's work might be interpreted within the general metaphorical frame of Politics Is An Object. Parliament might be understood as a Sacred And Valuable Object, which may explain György Fekete's indignation. He would probably have had a similar response to Andres Serrano's work: Christ on the cross, and the cross soaked in piss. The conception of the Parliament as a sacred and valuable object could lead to at least two possible interpretations: (1) Parliament should not be desecrated, because it has value, or (2) Parliament is not valuable now because it has been tainted, and hence should be cleansed. Andres Serrano accepts the second interpretation, and he lists his work among the Christian 
artworks, drawing attention to the fact that we cannot walk away indifferently when it comes to the cross of Christ. Shocking and shaking people are among his goals and the second interpretation may shock people into action.

A competing frame that goes against the concept of a valuable object is the interpretation of the Parliament As A Worthless Object (trumpery). In this case a Hungarian saying, 'floating in the warm pee' acts as an anchor which might be connected to the metaphor in the context of the artwork. The saying refers to an accepted situation which is not good or bad for the person who is in it; indeed, the person does not really do anything to improve the position. It is a kind of existence without any goals and motivations, just letting time pass. Here, the symbol of the parliament has no real value, so its placement in the urine does not violate any taboo. It aims to describe the situation represented by the parliament; namely, that the Hungarian democracy somehow works without goals and motivations. Szabó's conception might be understood within this metaphoric frame, but the interpretation is not forced on the viewer, who can freely choose among the frames.

\section{EXAMPLE 3: BORSOS LŐRINC, UNMOVABLE LAND 2010 (CHAMOTTE, JARRING TABLE)}

The artist couple, Borsos Lörinc made an installation in the form of a chamotte mock-up of parliament (Figure 4). Their mock-up is placed onto a vibrating table (originally used to solidify the concrete). The engine causing the vibration only starts when viewers' approach the piece. The fragile mock-up is expected to collapse, but if the viewer maintains sufficient distance, the table will not move at all.

Unmovable land can be compared to Dezső Szabó's work Piss Parliament from various aspects. Both of them deal with biblical citations and may work in the general metaphoric frame of Politics Is An Object. In the case of Szabó's art piece, the parliament is an analogue of Christ's cross and may be interpreted as an object that asks moral questions. The viewer's relationship to the Piss Parliament remains passive. He cannot influence the processes, but he may choose among the frames. Borsos Lőrinc's work cites a part of New Testament (to the Hebrews, 12:26-27):

Yet once more will I make to tremble not the earth only, but also the heaven. And this 'word', Yet once more, signified the removing of those things that are shaken, as of things that have been made, that those things which are not shaken may remain. 
Figure 4. Borsos Lőrinc (2010). Unmovable land, chamotte, jarring table

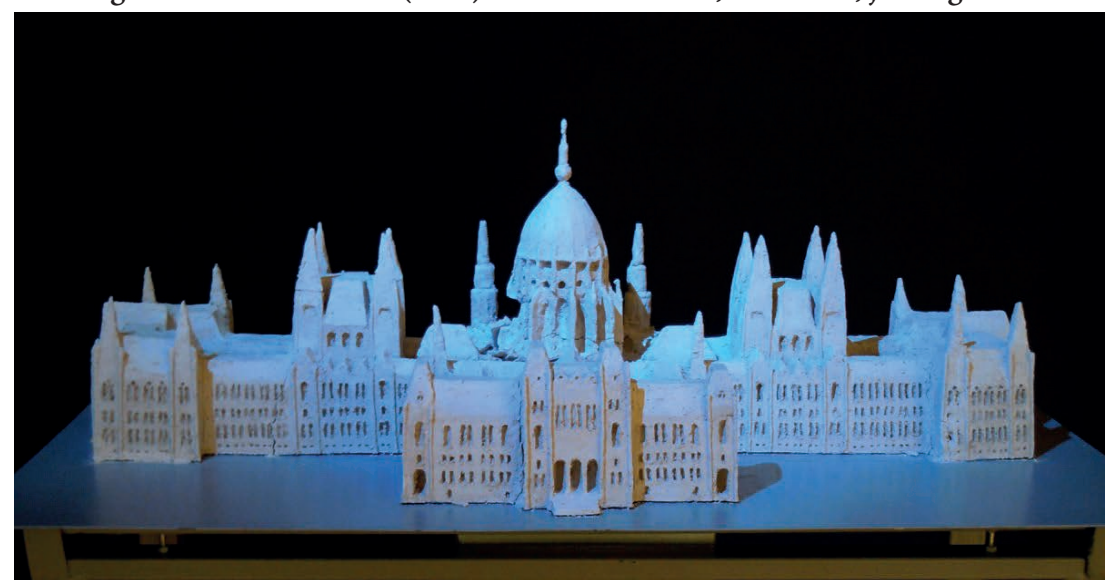

Regarding Unmovable land, the viewer is active. He can participate in the piece, but he can also refuse the act of participation, and so it is also about taking responsibility. The dependent relationship between the vibrating table and the viewer reflects, "a stable symbol that begins to erode, for which we are all responsible, and everybody has role in the process" (personal communication, April 28, 2017). According to the first frame, Parliament As A Valuable Object, which should not be demolished (e.g., there were reactions from the viewers' side who considered parliament a valuable object and as a result were sad about the destruction of the mock-up). If we accept the title of the artwork, Unmovable land as a positive statement then the piece functions in the mentioned frame.

Within the second frame, Parliament Is A Worthless Object and it should be demolished. If the viewer accepts this metaphor, then he is glad, because of the radical changes and moves around the mock-up happily. He intends to end and abolish things from the earth which have no real value for him. If we accept the title, Unmovable land as a negative statement, then unmovable land is a country that is not able to transform, it is closed off from the modern world, which is featured by mobility.

A third frame might occur when the Parliament Should Be A Value, so deep structural transformation is necessary. It is also possible to understand Unmovable land ironically, where the meaning of the statement becomes its opposite, so that we view the country as movable. This frame takes place between the two radical standpoints. The viewer feels that the symbol should not be demolished, but there is a need to change or at least modify the values. János Borsos' statement can be interpreted using the last two frames: "We wanted to highlight how people themselves feel here. We wanted to present an alternative country image with our things" (ibid.). The viewer may choose among the potential frames here as well. 


\section{EXAMPLE 4: BIANKA DOBÓ, CLEAN COURT, TIDY HOUSE 2014 (ACRYLIC, MAP, PLEXIGLASS, LED)}

Bianka Dobó made a three-part series with the title Workers. Figure 5 displays one of its pieces called Tiszta udvar, rendes ház ('Clean court, tidy house') that describes the building of the Hungarian Parliament. Its second piece shows the institute of the National Gallery which is located in Buda Castle, its title is 'Türelem rózsát terem' ('Patience is a virtue'). The third part depicts the Heroes' Square, and its title is 'Ki korán kel, aranyat lel' ('The early bird gets the worm'). All works show physical workers. Bianka Dobó lives and works in districts of Budapest that at the time had been under construction. As such she saw the parliament and Heroes' Square during her daily commute, and transformations of the various urban areas became not only part of her life but also significant motifs in her artworks.

There are buildings which are overhyped ('gets too much attention'), all tourists want to go there, because they are advertised in their guide books. The Parliament carries extra meaning beyond the touristic appeal of the physical building, it is linked to power. It has dense meaning among people, because it is a symbol (personal communication, April 4, 2018).

Figure 5. Bianka Dobó (2014). Clean court, tidy house, acrylic, map, plexiglass, led

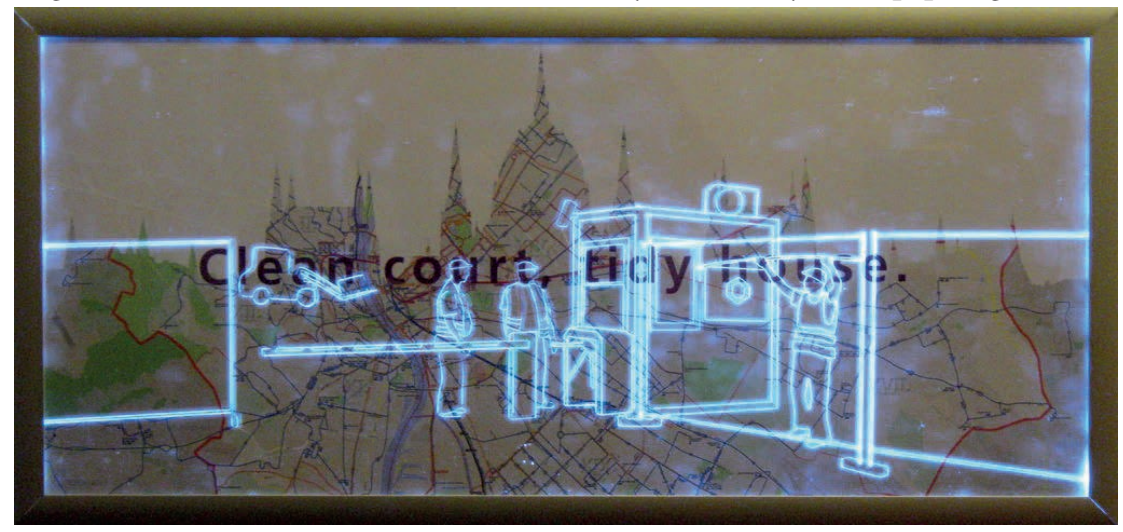

We may interpret Dobó's art pieces as a series of cityscapes which can belong to the general metaphoric frame Politics Is Landscape/Cityscape. The urban space planning around the parliament can be understood as actual 'tidying up', with the title of the painting, Clean court, tidy house being considered a positive statement. This interpretation can be motivated by the fact that the saying is used in countryside (Figure 6), and is often stated on boards placed by the outer walls of Hungarian cube houses so as to let people know that the person who lives there keeps a neat house. This habit usually has positive connotations and 
people upholding this habit are seen as being a good example to others. This interpretation of the artwork strongly depends on cultural knowledge, and most probably the motivated literally understanding of the title cannot be understood without this knowledge.

The second possible frame competes with the first one, in that we may comprehend the title ironically, so we assume the opposite of Clean court, tidy house. This raises questions along the lines of whether "there is corruption, there are sort of 'mutyi' (dirty affairs) or whether everything is okay in the legislative process" (ibid.). In this case Urban Space Planning Around The Parliament Is Not A Real Measure.

Within the third frame the motifs of the urban space planning are understood symbolically. The general frame, Politics Is Landscape/Cityscape changes, and another metaphoric frame comes to the fore, namely Politics Is War. Urban planning motifs are invisible, but knowledge about the concrete sites and the press coverage concerning spatial planning might be recalled. The flower beds and water pools for example, may be considered as obstacles against demonstrations by the opposition. Here, urban space planning around the parliament is understood as a process of preparing for a possible war, or conflict. The site is transformed for the battle, in which the parliament is the potential target. "It is a kind of defense. The square is surrounded by bastions, but you do not even realize that the parliament cannot be attacked, it is protected skillfully" (ibid.). To be able to recall the frame of WAR, it is necessary to follow the news on local politics, and hence, this interpretation is likely to be prominent among people who are against the government. For the artist Bianka Dobó, the parallel existence of competing frames, ironic interpretations, and context modifications are the most important processes within her artwork. The essence of her artworks is the creation of ambivalence in an intellectual way: "I am not that direct, concrete type of person. I also had debates as a result of my stance as some people find me too indirect or euphemistic" (ibid.).

It might be stated that Workers is a series that provides competing frames for its audience. In the first two cases the metaphor Politics Is Landscape/Cityscape is activated, while in the third case the metaphor Politics Is War occurs.

\section{EXAMPLE 5: KRISZTA NAGY TERESKOVA, KRISZTA NAGY IS CHAIRING IN FRONT OF THE PARLIAMENT BECAUSE SHE IS CHAIRING BETTER THAN HER COMPATRIOTS IN THE PARLIAMENT 2006 (PHOTO, TEXTUAL STATEMENT, VIRTUAL SHIT DELIVERY PROGRAM)}

Tereskova's artwork (Figure 6) responds to the domestic political events of 2006 and their aftermath. The now ex-Prime Minister, Ferenc Gyurcsány's speech (known as speech of Balatonőszöd), which was given in a private meeting of the Hungarian Socialist Party, was leaked to the press on September 17, 2006. The 
public received it with indignation, and protests began on the Kossuth Square in front of the Parliament, where people demanded the resignation of the PM and called for new elections. The riot police managed to disband the crowd on October 23, 2006 (which was a national holiday, the 50th anniversary of 1956). The aggressive and bloody clashes were broadcasted by the media and appeared on social media as well.

Figure 6. Kriszta Nagy Tereskova (2006). Kriszta Nagy is chairing in front of the Parliament because she is chairing better than her compatriots in the parliament, photo, textual statement, virtual shit delivery program

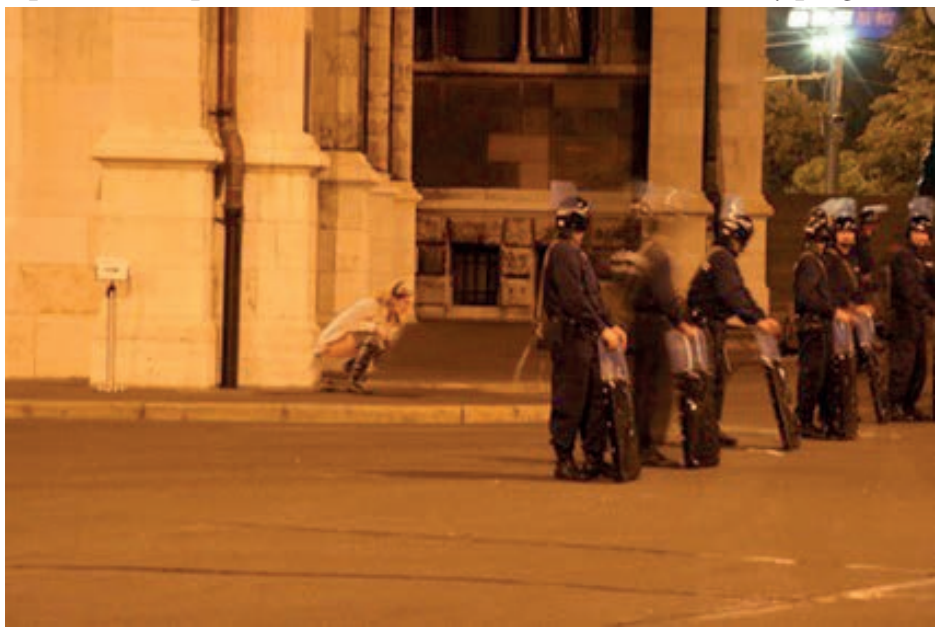

Tereskova initially published her photo in which she is squatting behind the row of the riot policemen at the corner of the parliament, after the speech came to light. She subsequently added a virtual shit delivery program and a verbal manifesto to the photo:

the Hungarian patriots cannot chair (to shit) better than Kriszta Nagy. You can also chair (to shit) better than our politicians. They absolutely shit on us (do not care about us) independent from their party affiliation, and from their power. In case you cannot believe anything, whether am I lying... if you feel that those people who are there for us, but shit on us... if you are disillusioned, but you do not want to participate in grand or small assemblies, because you lost your trust and you do not feel like being a pawn in the career path of leaders driven by the desire for power... then you can send a pink box of shit through this shit delivery system. By October 23 , it will become a wall in front of the building, we can cause constipation and they will swim in shit (literally in the Hungarian version 'shit will fall to their necks') (Tereskova). 
People who were familiar with the verbal text of the PM's speech - which included the expression 'shit' eight times with its range of symbolic meanings - can understand the artist's brilliant play on that. Ferenc Gyurcsány used the following phrases: 'being in shit' (being in trouble), 'distribute the shit among each other' (having meetings and talks without solutions), 'shit on something' (do not care about something), 'scared shitless' (being afraid of somebody), and 'horseshit' (bullshit). The artist visibly expanded the series of list including both and beside the conventional phrases such as 'to chair' (to shit) and 'swimming in shit' (all the troubles reach him), invented as well as novel phrases as well, such as 'to send virtual shit' (to express your opinion) and 'to cause constipation' (to take revenge).

She uses both the frames of Politics As An Object or as a Conflict, in which the Parliament Is A Worthless Object (as in you can shit on it or do not care about it) but at the same time it is also a toilet (Parliament Is A Toilet). This is motivated by the multimodal metaphor according to which The Expression Of The Opinion Is Shitting Or Virtual Shit Delivery.

An alternative frame, Politics Is War is produced when Tereskova times the 'shit delivery' by setting a target and a deadline (October 23) for her comrades. This act transforms a simple opinion expressing dissatisfaction and disillusion into a war against the political elite chairing the parliament. Here the metaphor Parliament Is A Fortress can be identified, as The Expression of Opinion Is A Revolutionary Act. Within this metaphoric scenario, Tereskova becomes the military leader, members of the population her potential army, shit and shit delivery the weapons, while the political elite is their enemy.

Like Borsos Lörinc's and Szabó's works, viewers can also maintain that the Parliament Is A Valuable Object, and in this case, Tereskova's action is dismissed by them as a vulgar, inappropriate behavior. This would contradict the two previous frames which relate to the viewer in different ways. In the first case (Toilet), the reception is passive while in the second (War), it becomes an active and collaborative act.

\section{EXAMPLE 6: ANDRÁS CSÉFALVAY, COMPSOGNATION: NATION STATE THROUGH THE EYES OF A DINOSAUR 2012 - 2014 (VIDEO)}

András Cséfalvay, a Bratislava-born artist describes his video on his website (http://www.andrascsefalvay.com/works30) as follows:

Compsognation or the concept of the nation state beheld with the eye of a dinosaur is a work, a filmic report of a dialogue and a Budapest walk with Compsognathus Longipes. Through our discussion we focus on the Compsognatus' view on nation, and the cancerous metasthatic category system 
of language and how it processes and divides up reality. Is it not possible, that a culture which has inhabited this planet for hundreds of millions of years will provide a substantially different and valuable view on the earlier mentioned sets of relations?

Cséfalvay sets up a metaphoric scenario of Walking in which The History Of The Mankind Is A Walking, The Parable/Message (Mediated By The Dinosaur) Is A Guide(Book), and An Angel/Mediator Is A Dinosaur. He presents two clashing ideological frames, Nationalism and Liberalism within the metaphoric scenario of the narrated dialogue between the two protagonists. According to the nationalist view, Nationalism Is A Painful Emotion/Cancer, Nation Is An Artificial Community With One Mother Tongue, Language Is A Supervisor, while The Parliament Stands For Too Much Pride (part of the Nationalism frame). In parallel, following the liberal perspective, Nation Is A Community With Multiple Languages, Language Is The Ship Of The Stories, and The Danube Stands For The Fluidity And Fluency (part of the frame Liberalism).

Figure 7. András Cséfalvay (2012 - 2014). Compsognation: Nation state through the eyes of a dinosaur, video

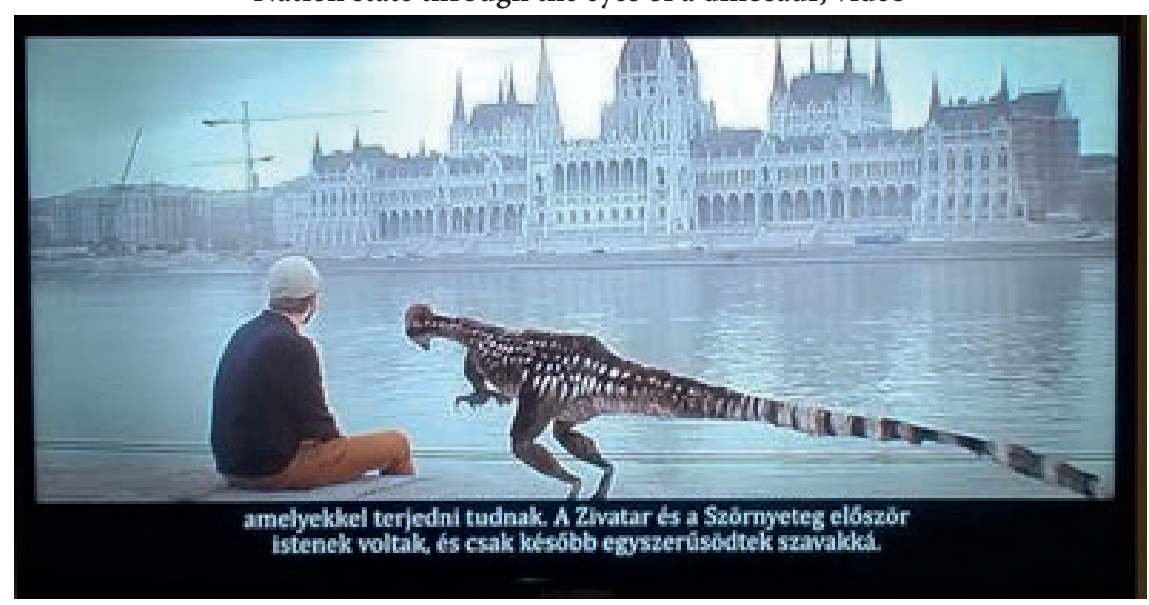

Overall, the symbolic representation of the parliament and River Danube metonymically stand for associations linked to various views. Whether the parliament is considered a negative or a positive symbol highly depends on the viewer's attitude and worldview. While the parliament belongs to the Nationalism frame in both cases, its evaluation differs greatly. The entire shot - when the man and the dinosaur are philosophizing about the relation between nation and language on the riverbank - evokes the metaphorical frames in which Politics Is Landscape (part of the frame View in which the ideology is represented through the image of a place) and Politics Is Conflict (between the views, nationalism and liberalism). The artist's main 
statement emphasizes that concept of nation does not cover the concept of language (on the basis of the interview conducted with Cséfalvay, March 21, 2018).

\section{EXAMPLE 7: ÁGNES EPERJESI, WORDS OF POWER APRIL 13, 2015 (SERIES OF SPEECH PERFORMANCES)}

Ágnes Eperjesi scheduled a series of performances (documentation is available on her website: http://www.eperjesi.hu/solo/hatalmi-szoval-words-of-power-1-23 ?id=240) that took place in spaces that reflect different levels of power. The first was held in the parliament, the second in a theatre (Back Gate), and the third on the Szabadság Square (Square of Liberty) and the places refers to the various levels of power and attention towards each other (artist's comment on her work during an interview, April 18, 2018). Eperjesi adds that this was 0 degrees in the parliament condition given the timing of the speech (1.30 AM) and due to the impossibility of responding in this political genre (speech after the agenda). "Parliament is the place of lawmaking and it is the peak of power" (detail from the interview with Eperjesi).

Figure 8. Ágnes Eperjesi (April 13, 2015). Words of Power, series of speech performances. (Parliament performance: April 13, 2015. Photos: The Orbital Strangers Project. Retrieved March 1, 2021 from http://www.eperjesi.hu/protest/ hatalmi-szoval-1-performansz-a-parlamentben-performance-in-parliament?id=180).
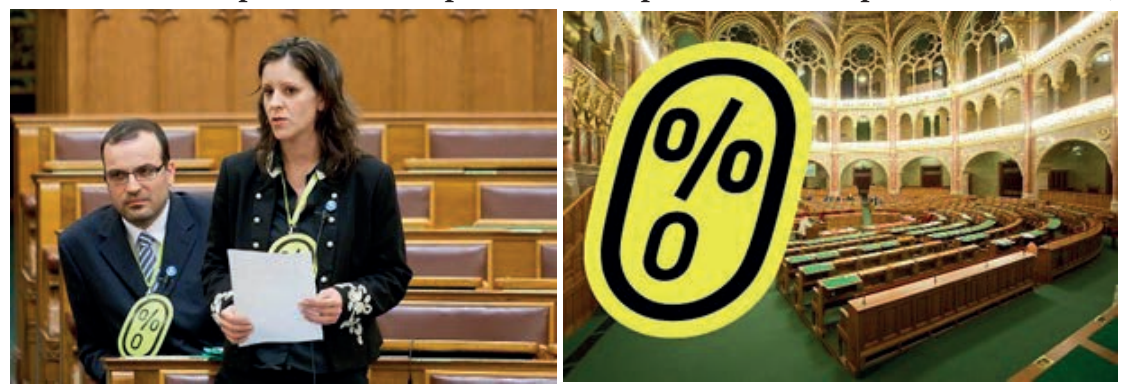

The title of the series - Words of Power ('Hatalmi szóval' in Hungarian) - refers to power as an institution that has the right to hold speeches (Power Is Force) and also reflects on the speech that must reach power (Power Is A Destination). The latter is symbolized by a screaming mouth on a yellow lanyard card while the \% sign stands for money on which power is based, created by Imre Lepsényi.

The first performance was presented by independent parliamentary representatives and those of the opposition parties as part of the questioning session (at 1.30 AM April 13, 2015). Four powerful reused speeches included the Polish ex-PM, Ewa Kopacz's text on the silence of the majority, the Estonian ex-President, Thomas Hendrik Ilves's text on annexation and justice, the ex-PM of Uruguay, 
Jose Mujica's text on the civilizational model, and finally, the ex-PM of Australia, Julia Gillard's text on sexism and misogyny. Texts were rehaped by Péter Kárpáti.

Eperjesi applies the Conflict frame, more specifically The Conflict Of Communication frame, which is mainly triggered by the subordinate position of the opposition parties and the voters represented by them. On the one hand, a viewer can claim that the speeches are successful in the sense that they were allowed to be given in the Assembly Hall without violent silencing and fines. The Parliament in this instance metonymically Stands For A Significant Place where powerful communication happens. On the other hand, another viewer probably would not consider the speeches successful or would be indifferent given the circumstances within which they were presented (time and number of a few participants, etc.). Here, a sharp conflict over the power develops as the speeches are completely neglected, and hence Parliament metonymically Stands For An Insignificant Place where communication cannot take place properly.

\section{DISCUSSION AND CONCLUSION}

As stated in the introduction, this article provides an overview of the multiple possible interpretations of artworks that show the parliament through the use of competing frames or alternative specifications of certain frames despite the exclusion of direct political references (Table 1). This does not mean that the artists do not have their own private opinion, but that is not the subject of their artwork. As stated by Terkildsen and Schnell (1997), a similar approach is also characteristic of fair and impartial journalism which aims to present multiple points of view at the same time. The influence on the audience through this refined communicative manner is described by Eperjesi as follows (detail from the interview, April 4, 2018):

Events that occur in the Parliament and texts spoken there, have a symbolic value, the strength of which I wouldn't underestimate. I believe that symbolic sentences and acts work from top to bottom. Therefore, it is important what those who are in power say and do, because their impact is obvious. It leaks down pretty slowly and soaks through all strata of society.

The first research question asked whether it is possible to identify any of the generic frames in artworks showing the parliament. According to the analyses, the most preferred frames are Politics Is Object and Politics Is War (Conflict), but the sources Landscape and Game are also used. Some artists also apply multiple frames simultaneously. Besides the use of conventional metaphoric frames, artists applied creative ways to allow the viewers to reflect on the problems raised. 
The solutions ranged from the use of a non-typical type of source (Figure 2), a non-typical frame added to the common one (Christianity) (Figure 3, 4), the use of local-cultural contextual knowledge (saying) (Figure 5), knowledge on the political discourse at the time (Figure 6), use of national symbols embedded in a specific metaphoric scenario (Figure 7), and finally, the collaboration with those in power (politicians) (Figure 8).

The second question asked what sorts of emerging ideologies can be detected within the parliament-representations and how are they realized within the frames offered. Some artworks present a system critical position, suggesting that society tolerates childish politicians, or even worse, that citizens behave as children (Figure 2), while other artworks suggest members of the society are politically indifferent (Figure 3), or responsible as citizens, as the lack of political activity is questioned (Figure 4). The artworks presented in Figure 5 and 6 suggest that members of the society can choose between the role of a good worker/passive mute observer or the role of a rebel, while the silent but also silenced masses is reflected in Figure 8. Finally Figure 7 draws attention to the dangers of extreme nationalist views and advocates tolerance and openness.

Following the characteristic features of framing as identified by Entman (1993), it can be claimed that the frames activated via the artworks aim to reveal shortcomings in the democratic process by highlighting the immoral political elite, the lack of social activity, and the lack of real dialogue among the parties. All of which can cause stagnation or 'still waters' in contrast to the desired prosperous economy. The art pieces point to the indifference and passivity of the citizens as a reason for these issues. The frames use critical, ironic and moral evaluations and provide access to multiple worldviews. They suggest radical change in the attitude of both the political elite as well as the citizens as a possible solution.

The present paper does not state that all political artworks use the strategy of competing frames, but rather that the political topics that are presented in art may well be linked to one of the five metaphoric frames determined in the field of political communication. To fully understand the symbolic meaning within the artworks that show the Hungarian Parliament, conventional knowledge about the possible metaphoric interpretations of politics does seems necessary. Understanding and applying the theory of competing frames is a forward-looking approach that allows the artworks to accommodate the viewer's perspective and thinking. 
Table 1. Competing frames identified in the investigated examples

\begin{tabular}{|c|c|c|c|}
\hline Artwork & Frame 1 & Frame 2 & Frame 3 \\
\hline $\begin{array}{l}\text { Marko Rodics, } \\
\text { Parliament, } 2010\end{array}$ & $\begin{array}{l}\text { Politics Is Game } \\
\text { Parliament Is } \\
\text { A Playhouse } \\
\text { Politicians Are Children } \\
\text { (Metaphorical framing) }\end{array}$ & $\begin{array}{l}\text { Politics Is Game } \\
\text { Parliament Is } \\
\text { A Plush Toy } \\
\text { Voters Are Children } \\
\text { (Metaphorical framing) }\end{array}$ & \\
\hline $\begin{array}{l}\text { Dezső Szabó, Piss } \\
\text { Parliament, } 2009\end{array}$ & $\begin{array}{l}\text { Politics Is An Object } \\
\text { Politics Is A Sacred } \\
\text { \& Valuable Object } \\
\text { (Framed by hyperbolic } \\
\text { metaphor, positive) }\end{array}$ & $\begin{array}{l}\text { Politics Is An Object } \\
\text { Politics Is A Worthless } \\
\text { Object } \\
\text { (Framed by hyperbolic } \\
\text { metaphor, negative) }\end{array}$ & \\
\hline $\begin{array}{l}\text { Borsos Lőrinc, } \\
\text { Unmovable land, } 2010\end{array}$ & $\begin{array}{l}\text { Parliament Is An Object } \\
\text { Parliament Is } \\
\text { A Valuable Object } \\
\text { (Framed by a } \\
\text { hyperbolic metaphor, } \\
\text { positive) }\end{array}$ & $\begin{array}{l}\text { Parliament Is An Object } \\
\text { Parliament Is } \\
\text { A Worthless Object } \\
\text { (Framed by a } \\
\text { hyperbolic metaphor, } \\
\text { negative) }\end{array}$ & $\begin{array}{l}\text { Parliament Is An Object } \\
\text { Parliament Should } \\
\text { Be A Value } \\
\text { (Framed by an } \\
\text { ironic metaphor) }\end{array}$ \\
\hline $\begin{array}{l}\text { Bianka Dobó, } \\
\text { Clean court, tidy } \\
\text { house, } 2014\end{array}$ & $\begin{array}{l}\text { Politics Is A Landscape } \\
\text { / Cityscape } \\
\text { Parliament Is } \\
\text { A Tidy House } \\
\text { (Framed literally, } \\
\text { based on its title) }\end{array}$ & $\begin{array}{l}\text { Politics Is A Landscape } \\
\text { / Cityscape } \\
\text { Parliament Is } \\
\text { A Tidy House } \\
\text { (Framed ironically, } \\
\text { based on the assumed } \\
\text { opposite of its title) }\end{array}$ & $\begin{array}{l}\text { Politics Is War } \\
\text { Parliament Is A Potential } \\
\text { Military Target } \\
\text { (Metaphorical framing) }\end{array}$ \\
\hline $\begin{array}{l}\text { Kriszta Nagy Tereskova, } \\
\text { Kriszta Nagy is } \\
\text { chairing in front of the } \\
\text { Parliament because } \\
\text { she is chairing better } \\
\text { than her compatriots in } \\
\text { the parliament, } 2006\end{array}$ & $\begin{array}{l}\text { Politics Is An Object } \\
\text { Parliament Is } \\
\text { A Valuable Object } \\
\text { (Metaphorical } \\
\text { framing, positive) }\end{array}$ & $\begin{array}{l}\text { Politics Is An Object } \\
\text { Parliament Is } \\
\text { Toilet/A Worthless Object } \\
\text { (Metaphorical } \\
\text { framing, negative) }\end{array}$ & $\begin{array}{l}\text { Politics Is War } \\
\text { Parliament Is A Fortress } \\
\text { (Metaphorical framing) }\end{array}$ \\
\hline $\begin{array}{l}\text { András Cséfalvay, } \\
\text { Compsognation: Nation } \\
\text { state through the eyes of } \\
\text { a dinosaur, } 2012-2014\end{array}$ & $\begin{array}{l}\text { Politics Is Landscape } \\
\text { Politics Is Conflict } \\
\text { (Between Nationalist } \\
\text { And Liberal Views) } \\
\text { Parliament Stands } \\
\text { For National Symbol } \\
\text { / National Pride } \\
\text { (Framed } \\
\text { metonymically, } \\
\text { positive) }\end{array}$ & $\begin{array}{l}\text { Politics Is Landscape } \\
\text { Politics Is Conflict } \\
\text { (Between Nationalist } \\
\text { And Liberal Views) } \\
\text { Parliament Stands For } \\
\text { National Symbol / Too } \\
\text { Much National Pride } \\
\text { (Framed by } \\
\text { a hyperbolic } \\
\text { metonymy, negative) }\end{array}$ & \\
\hline $\begin{array}{l}\text { Ágnes Eperjesi, } \\
\text { Words of Power, } \\
\text { April 13, } 2015\end{array}$ & $\begin{array}{l}\text { Politics Is Conflict } \\
\text { Of Communication } \\
\text { Parliament Stands For } \\
\text { A Place Where Successful } \\
\text { Communication } \\
\text { Takes Place } \\
\text { (Framed } \\
\text { metonymically, } \\
\text { positive) }\end{array}$ & $\begin{array}{l}\text { Politics Is Conflict } \\
\text { Of Communication } \\
\text { Parliament Stands } \\
\text { For A Place } \\
\text { Where 'Successful' } \\
\text { Communication } \\
\text { Takes Place } \\
\text { (Framed } \\
\text { metonymically } \\
\text { combined with ironical } \\
\text { approach, negative) }\end{array}$ & \\
\hline
\end{tabular}

Source: Author 


\section{ACKNOWLEDGEMENTS}

The author would like to thank the two anonymous reviewers for their inspiring questions and helpful comments on the manuscript. My thanks also go to Prof. Stanley Ward and Marlies de Groot for the English language corrections. I am grateful to the artists for their contributions to the interviews and also to the publication of the reproductions of their works. The present research was made possible by the Ernő Kállai Scholarship for art historians and art critics supported by the Hungarian state.

\section{REFERENCES}

Artportal (2015, December 23) Régi dilemmák kora. Intézményi körkép 2015 végén [The Age of Old Dilemmas. Institutional Overview at the end of 2015]. Retrieved November 23, 2018 from https:// artportal.hu/magazin/regi-dilemmak-kora-intezmenyi-korkep-2015-vegen/.

Balázs, K. (2018). La Fête permanente: Magyar résztvevők az 1987-es documenta 8 performansz-szekciójában [La Fête permanente: Hungarian participants in the performance section of Documenta 8 of 1987], Artmagazin, 16 (10): 35-43.

Bárczi, G. \& Országh, L. (1959-62/2016). A magyar nyelv értelmező kéziszótára [Interpretative Dictionary of the Hungarian Language]. Hungarian Academy of Sciences. Retrieved September 25, 2018 from http://mek.oszk.hu/adatbazis/magyar-nyelv-ertelmezo-szotara/kereses.php?kereses=parlament.

Burgers, C., Konijn, E. A., \& Steen, G. J. (2016). Figurative framing: Shaping public discourse through metaphor, hyperbole and irony. Communication Theory, 26(4): 410-430.

Brugman, B. C., \& Burgers, Ch. (2018). Political framing across disciplines: Evidence from 21st century experiments. Research and Politics, 5(2), DOI: https://doi.org/10.1177\%2F2053168018783370.

Brugman, B. C., Burgers, Ch. \& Steen, G. (2017). Recategorizing political frames: a systematic review of metaphorical framing in experiments on political communication. Annals of the International Communication Association, 41(2): 181-197.

Cappella, J. N., \& Jamieson, K. H. (1997). Spiral of Cynicism: The Press and the Public Good. Oxford University Press.

Carroll, N. (1994). Visual metaphor. In: J. Hintikka (Ed.), Aspects of metaphor. Dordrecht: Kluwer.

Entman, R. M. (1993). Framing: Towards clarification of a fractured paradigm. Journal of Communication, 43(4): 51-58.

Forceville, C. (1988). The case for pictorial metaphor: Tené Magritte and other Surrealists. In Aleš Erjavec (Ed). Vestnik 9. Ljubljana, YU: Inštitut za Merksistićne Študije, 150-160.

Freemuse Report (2019). Retrieved February 19, 2019 from https://freemuse.org/resources/item/thestate-of-artistic-freedom-2019/.

Goffman, E. (1974). Frame analysis: An essay on the organization of experience. Harvard University Press. Gombrich, E.H. (1963). 'The Cartoonist's Armoury'. In E. Gombrich (Ed.), Meditations on a Hobby Horse and Other Essays on the Theory of Art. London: Phaidon. 
Krippendorff, K. (2017). Three concepts to retire. Annals of the International Communication Association, 41(1): 92-99.

Kristóf, L. (2017). Cultural Policy in an Illiberal State: A Case Study of Hungary after 2010. Intersections East European Journal of Society and Politics, 3(3): 126-147.

Lakoff, G., \& Johnson, M. (1980). Metaphors We Live By. University of Chicago Press.

Lakoff, G. (1996). Moral Politics: What Conservatives Know That Liberals Don't. University of Chicago Press.

Ludwig Lépcső - Összefogás a Kortárs Művészetért [Ludwig Stairs - Teamwork for Contemporary Art]. (2013, July 23) nemma. Retrieved January 3, 2019 from https://nemma.noblogs.org/2013/07/23/ ludwig-lepcso-osszefogas-a-kortars-muveszetert/.

Magyar Narancs (2012, December 31). “A foglyul ejtett Mücsarnok” [Kunsthalle has been captured]. Retrieved November 21, 2018 from https://magyarnarancs.hu/kultura/tuntetes-es-mellebeszeles-a-mucsarnokban-83086.

Minőség a kultúrában [Quality in Culture, cultural policy program guide] (2009). Cultural Strategical Basics of Hungary. Retrieved November 26, 2018 from http://static-old.fidesz.hu/download/_17/ Szakpolitikai_fuzetek_2_BELIV__2009_02_17.pdf.

Népszava. (2018, July 28) Orbán új korszakot és kultúrharcot hirdetett Tusványoson [Orbán proclaimed a new era and cultural fight in Tusványos]. nepszava.hu. Retrieved December 4, 2018 from https:// nepszava.hu/3003117_orban-uj-korszakot-es-kulturharcot-hirdetett-tusvanyoson.

Patridge, L. (2005). A visual and textual framing analysis of terrorism: The case of Beslan. Iowa State University.

Poppi, F.I. M., \& Kravanja, P. (2019). Actiones secundum fidei: Antithesis and metaphoric conceptualization in Banksy's graffiti art. Metaphor and the Social world, 9(1).

Rodriguez, L., \& Dimitrova, D. V. (2011). The levels of visual framing. Journal of Visual Literacy, 30(1): $48-65$.

Rothenberg, A. (2008). Rembrandt's Creation of the Pictorial Metaphor of Self. Metaphor and Symbol, 23(2): 108-129.

Sniderman P. M., \& Theriault, S. M. (2004). The Structure of Political Argument and the Logic of Issue Framing, In: W.E. Saris \& P. M. Sniderman (Eds.), Studies in Public Opinion: Attitudes, Nonattitudes, Measurement Error, and Change. Princeton University Press.

Stampoulidis, G., \& Bolognesi, M. (2020). Bringing metaphors back to the streets: A corpus-based study for the identification and interpretation of rhetorical figures in street art. Visual Communication. Retrieved March 20, 2021 from https://journals.sagepub.com/doi/10.1177/1470357219877538.

Terkildsen, N. \& Schnell, F. (1997). How Media Frames Move Public Opinion: An Analysis of the Women's Movement, Political Research Quarterly, 50(4): 879-900.

De Vreese, C. H. (2005). News framing: Theory and typology. Information Design Journal + Document Design, 13(1): 51-62.

Vazallusok kora. Kultúrpolitikai helyzetfelmérő esszé [The Age of Vassals. Cultural Political Situation Assessment Essay]. (2014, December 22). Artportal. Retrieved November 19, 2018 from https://artportal.hu/magazin/vazallusok-kora-kulturpolitikai-helyzetfelmero-essze/.

Wischmann, L. (1987). Dying on the front page: Kent State and the Pulitzer Prize. Journal of Mass Media Ethics, 2(2): 67-74. 